\title{
MAGEC1 Gene
}

National Cancer Institute

\section{Source}

National Cancer Institute. MAGEC1 Gene. NCI Thesaurus. Code C104524.

This gene may play a role in embryonal development, tumor transformation, or tumor progression. 